\title{
Distribution of brominated flame retardants and phthalate esters in house dust in Korea
}

\author{
Deok-Jun Kweon, Moon-Kyung Kim, Kyung-Duk Zoh ${ }^{\dagger}$ \\ Department of Environmental Health Sciences, School of Public Health, Seoul National University, Seoul 08826, Republic of Korea
}

\begin{abstract}
We examined the levels of brominated flame-retardants (BFRs) including polybrominateddiphenyl ethers (PBDEs), tetrabromobisphenol-A (TBBPA), hexabromocyclododecane (HBCD), and phthalates in indoor dusts in residential houses in Korea, and their distribution patterns depending on building characteristics. Mean concentrations of phthalate esters $\left(1,825 \mu \mathrm{g} \mathrm{g}^{-1}\right)$ were significantly higher than that of BFRs (PBDE: 1,332 $\mathrm{ng} \mathrm{g}^{-1}$, HBCDs: $459 \mathrm{ng} \mathrm{g}^{-1}$, and TBBPA: $213 \mathrm{ng} \mathrm{g}^{-1}$ ), indicating more frequent use of phthalate-containing products such as PVC flooring in the Korean houses. PVC flooring house was associated with higher concentrations of DEHP $(p=0.001)$ and BBP $(p=$ 0.012), indicating that exposure to phthalate was higher in the PVC flooring house. Building age was significantly related with levels of PBDEs especially BDE-47 ( $p=0.062)$, BDE-203 $(p=0.007)$, DEHP $(p=0.004)$, and BBP $(p=0.070)$, respectively, indicating that older buildings can produce higher amounts of PBDEs and phthalates. Our study can provide important information on the sources of BFRs and phthalates in residential houses in Korea.
\end{abstract}

Keywords: Construction age, DEHP, House dust, PBDE, Phthalates, PVC flooring

\section{Introduction}

There has recently been increasing concern about chemicals that may disrupt the endocrine systems of humans and animals. One such group of chemicals is brominated flame-retardants (BFRs). BFRs, especially polybrominateddiphenyl ethers (PBDEs), tetrabromobisphenol-A (TBBPA), and hexabromocyclododecane (HBCD), have been widely used as fire retardants and plasticizers in numerous plastic products [1-3]. PBDEs can act as endocrine disruptors that mimic or interfere with the function of hormones, such as those in the thyroid gland [4]. Due to the risk posed by PBDEs, international movements to regulate their use in home appliances and plastic equipment have arisen, including the Restriction of Hazardous Substances Directive (RoHS) and the Waste Electrical and Electronic Equipment Directive (WEEE) [2].

The movement to regulate the use of HBCD and TBBPA, which are alternatives to PBDEs, has also emerged [5, 6]. HBCD is considered persistent and bio-accumulative, and might cause reproductive, developmental, and neurological disorders. TBBPA is known to have adverse effects on thyroid hormones.
Under the EU's REACH (Regulation, Evaluation, Authorization, and restriction of CHemicals) program, HBCDs were phased out in European trade by mid-2015 [5]. TBBPA was also registered under REACH in October 2010 [7, 8].

Phthalates have been widely used as plasticizers, added to plastics to increase their flexibility, transparency, durability, and longevity. They are used in a variety of electrical and electronic goods (connectors, capacitors, and cables), household applications (shower curtains, vinyl upholstery, food containers, and wrappers), and construction materials (adhesives, floor tiles, and wall coverings) [9]. Phthalates may mimic estrogenic hormones and have inhibitory developmental effects on humans [10, 11]. Among the phthalates, bis (2-ethylhexyl) phthalate (DEHP) in particular causes damage to the liver and testes [12]. As a result, an EU risk assessment classified DEHP, dibutyl phthalate (DBP), and benzyl butyl-phthalate (BBP) as hazardous substances in 2005, and has issued directives to ban these materials from products, particularly toys and cosmetics [13].

The sources of human exposure to BFRs and phthalates have been reported to be indoor environments and diet [14, 15]. Even
This is an Open Access article distributed under the terms of the Creative Commons Attribution Non-Commercial License (http://creativecommons.org/licenses/by-nc/3.0/) which permits unrestricted non-commercial use, distribution, and reproduction in any medium, provided the original work is properly cited.
Received January 2, 2018 Accepted March 2, 2018

${ }^{\dagger}$ Corresponding author

Email: zohkd@snu.ac.kr

Tel: +82-2-880-2737 Fax: +82-2-762-2888

Copyright (C) 2018 Korean Society of Environmental Engineers 
diet is a main source of PBDE and phthalate exposure, sources such as indoor house dust are also another significant human exposure routes. Recent studies reported that BFRs and phthalates in residential houses [16-18]. However, there are no studies on the measurement of both BFRs and phthalates together in indoor environment.

In this study, we determined the concentrations of the main BFRs (PBDEs, TBBPA, and $\alpha-, \beta-$, and $\gamma$-HBCD) and phthalate esters by analyzing settled house dust from residential houses in Korea. The results were compared to the levels reported in related researches in other countries. In addition, the correlations between the levels and building characteristics such as flooring type (PVC or wood) and building age were performed.

\section{Methods and Materials}

\subsection{Chemicals and Materials}

N-hexane (PRA grade) was purchased from SK chemical (Korea), ethyl acetate (HPLC grade) was purchased from Burdick \& Jackson (USA), and methanol (HPLC grade) was purchased from J.T. Baker (USA). Phthalate esters, PBDE congeners, $\alpha-, \beta-, \gamma$ -HBCD, and TBBPA were all purchased from Accustandard (USA).

The mixture standard solution of phthalate esters contained 15 kinds of phthalates; dimethyl phthalate (DMP), diethyl phthalate (DEP), diisobutyl phthalate (DIBP), DBP, bis(methoxyethyl) phthalate (DMEP), bis(4-Methyl-2-pentyl)phthalate (DMPP), diethoxyethyl phthalate (DEEP), diamyl phthalate (DAP), BBP, dihexyl phthalate (DHP), di(butoxyethyl)phthalate (DBEP), dicyclohexylphthalate (DCHP), bis(2-ethylhexyl) phthalate (DEHP), di-n-octyl phthalate (DNOP), and dinonyl phthalate (DNP). Likewise, the mixture standard solution of PBDE congeners was prepared by the product named 'Custom PBDE congeners' which was composed of 13 kinds commonly used in industry circle; 2-bromodiphenyl ether (BDE-1), 2,4-bibromodiphenyl ether (BDE-7), 2,4,4'-tribromodiphenyl ether (BDE-28), 2,2',4,4'-tetrabromodiphenyl ether (BDE-47), 2,2',4,4',5-pentabromodiphenyl ether (BDE-99), 2,2',4,4',6-pentabromodiphenyl ether (BDE-100), 2,2',4,4',5,6'-hexabromodiphenyl ether (BDE-154), 2,2',3,4,4',5',6heptabromodiphenyl ether (BDE-183), 2,2',3,4,4',5,5',6-octabromodiphenyl ether (BDE-203), 2,2',3,3',4,4',5,5',6-nonabromodiphenyl ether (BDE-206), 2,2',3,3',4,4',5,6,6'-nonabromodiphenyl ether (BDE-207), 2,2',3,3',4,5,5',6,6'-nonabromodiphenyl ether (BDE-208), and decabromodiphenyl ether (BDE-209). The mixture solution of HBCDs and TBBPA was prepared by mixing each single standard solution (Accustandard, USA) using methanol.

The deuterium ring-labelled reference materials of dibutyl-phthalate (di-n-butyl phthalate-3,4,5,6- $\mathrm{d}_{4}, \mathrm{DBP}-\mathrm{d}_{4}$ ) as a surrogate material for phthalates was purchased from Fluka (USA) [9]. 2,3,5,6-tetrachlorobiphenyl (PCB-65) as a surrogate for low mass PBDEs, HBCDs, and TBBPA was purchased from Accustandard [16]. Tetrachloro-m-xylene (TCMX) was purchased from Accustandard [16] and served as an internal standard, which calibrates final volumes and measuring sensitivity. PCB-166 was used as a surrogate for high mass PBDE congeners.

The individual stock solutions were prepared appropriately, and kept in a refrigerator at $4^{\circ} \mathrm{C}$.

\subsection{Sampling}

Dust samples were collected from residential houses $(n=42)$ from different indoor environments in Seoul and Kyung-Gi Province, Korea. During sampling, the factors such as residential type (22 apartments, 13 multiplex, and 7 single studio rooms), building construction age (before 1990, 1991 to 2000, and after 2001), and flooring materials (PVC linoleum and wood type) were also examined using a checklist form [19]. The detailed information of sampling houses is provided in the supplementary materials (Table 1).

Table 1. Summary of House Dust Sampling Information

\begin{tabular}{ll}
\hline Items & House \\
\hline Number of samples & 42 \\
Sampling period & May 2011 to September 2011 \\
Locations & Seoul/Kyung-gi Province \\
Sampling device & Vacuum cleaner \\
Remarks & Floor: PVC, Wood, laminate \\
& Ceiling and wall: laminated paper \\
Residential type & $\begin{array}{l}\text { Apartment (22), Multiplex (13), } \\
\text { Single studio room (7) }\end{array}$ \\
Floor material & $\begin{array}{l}\text { PVC (34), Wood (8) } \\
\text { Construction age }\end{array}$ \\
& Before 1990 (10), 1991-2000 (21), \\
& After 2001 (11) \\
\hline
\end{tabular}

Duplicate samples were obtained from the residential homes using a vacuum cleaner. After the sampling, large debris, hair and non-dust particles in the samples were removed using a coarse metal sieve. To avoid contamination, the collected samples were immediately transferred to amber glass bottles and stored at $20^{\circ} \mathrm{C}$ until analysis.

\subsection{Sample Extraction}

To reduce the risk of lab- and cross-contamination, the extraction method developed by Abb et al. [13] was used. A detailed description of the extraction and analysis procedures of BFRs and phthalates were provided in Fig. S1. Approximately $250 \mathrm{mg}$ of dust was put in a $30 \mathrm{~mL}$ extraction vial and added $20 \mathrm{~mL}$ of ethyl acetate and n-hexane solution (1:1). After spiking 50 $\mu \mathrm{L}$ of the surrogate which was the mixture solution made up of PCB-65 (40 $\left.\mu \mathrm{g} \mathrm{mL}^{-1}\right)$, PCB-166 (5 $\mu \mathrm{g} \mathrm{mL}^{-1}$ ), and DBP-d $\mathrm{d}_{4}(100$ $\mu \mathrm{g} \mathrm{mL}{ }^{-1}$ ) [9], the ultrasonic extraction was performed for 60 min at $40^{\circ} \mathrm{C}$, and then followed by letting them cool at room temperature. The amount of 2 spatulas of anhydrous sodium sulfate was added to each the extract for water elimination. The supernatant was filtered with a glass syringe (Jamsil Medical) and a hydrophobic filter (AD.25JP050AN, ADVANTEC) for a simple clean up thereafter.

Due to the lower concentrations but higher method detection 
limits of PBDEs, exactly $10 \mathrm{~mL}$ volume of each the extract was transferred with a volume pipette to a concentration vial separately, and then concentrated into $0.5 \mathrm{~mL}$ using nitrogen gas in a Turbovap®II (Zymark). The rest extracts was directly used to analyze phthalates with GC/MS and to analyze HBCDs/TBBPA with LC/MS/MS. Especially, since DEHP showed higher deviation far from the calibration range, each the extract was diluted to $1: 10$ or 1:100 with n-hexane in additional vials. The final extract for phthalates and HBCDs/TBBPA were carried to the $2 \mathrm{~mL}$ vials and set up to $1.5 \mathrm{~mL}$ as final volume, but that for PBDEs were set up to $0.5 \mathrm{~mL}$. Prior to analyze them, an internal standard, TCMX $\left(2 \mu \mathrm{g} \mathrm{mL}^{-1}\right)$ were spiked into them skillfully. Each sample was analyzed in duplicate for each determination [20].

\subsection{GC/MS Analysis}

After the extraction, PBDEs and phthalates were analyzed by GC/MS (Perkinelmer Clarus-500). The separation of PBDEs was operated by a DB-5MS capillary column $(15 \mathrm{~m} \times 0.25 \mathrm{~m} \times$ $0.1 \mu \mathrm{m})$. The samples were injected by an amount of $1 \mu \mathrm{L}$ in splitless mode. Helium was used as carrier gas at constant flow ( $1 \mathrm{~mL} \mathrm{~min}^{-1}$ ) and nitrogen was used as make-up gas at constant flow ( $4 \mathrm{~mL} \mathrm{~min}^{-1}$ ). The temperature condition was programmed from $80^{\circ} \mathrm{C}$, kept for $1 \mathrm{~min}$, then increased with $10^{\circ} \mathrm{C} \min ^{-1}$ to $170^{\circ} \mathrm{C}$, kept for $2 \mathrm{~min}$, then increased with $10^{\circ} \mathrm{C}$ $\mathrm{min}^{-1}$ to $260^{\circ} \mathrm{C}$, kept for $0 \mathrm{~min}$, and then increased with $20^{\circ} \mathrm{C}$ $\min ^{-1}$ to $300^{\circ} \mathrm{C}$, kept for $8 \mathrm{~min}$, so took totally $31 \mathrm{~min}$. The MS was operated with a selected ion monitoring (SIM) mode in electron ionization inner source. The ion source, quadruple, and interface temperature were 300,280 , and $300^{\circ} \mathrm{C}$, respectively.

The determination and separation of phthalates using GC/MS were as follows; the column is different from PBDEs, which was DB-5MS capillary column (30 $\mathrm{m} \times 0.25 \mathrm{~m} \times 0.25 \mu \mathrm{m})$. The injection volume was $1 \mu \mathrm{L}$ in split mode (20:1) and injector temperature was $260^{\circ} \mathrm{C}$. The temperature condition was set from $100^{\circ} \mathrm{C}$, kept for $4 \mathrm{~min}$, and then increased with $10^{\circ} \mathrm{C} \mathrm{min}^{-1}$ to $260^{\circ} \mathrm{C}$, kept for $10 \mathrm{~min}$, so took $30 \mathrm{~min}$ in total. The ion source quadruple and interface temperature were all $280^{\circ} \mathrm{C}$. The other conditions were identical with PBDEs.

The contamination of extraction solvents (n-hexane and ethyl acetate) with BFR and phthalate ester residues was also checked by LC/MS-MS.

\subsection{LC/MS/MS Analysis}

The determination of $\Sigma$ HBCDs and TBBPA was achieved using a MS/MS system of AB-Sciex (Q-Trap 3200) and a HPLC system of Perkinelmer (FX HPLC system). $\alpha$-, $\beta$-, and $\gamma$-HBCD and TBBPA were to be separated and quantified in one method with Thermo CCS Hypercarb C18 column $(150 \times 4.6 \mathrm{~mm}$ i.d., $5 \mu \mathrm{m}$ particle size). A mobile phase of de-ionized water and methanol at a flow rate of total $400 \mu \mathrm{L} \mathrm{min}{ }^{-1}$ was applied for elution of HBCD isomers. The mobile phase flowed at the gradient condition whose step was starting 90\% methanol was held for 1 min then decreased linearly to $10 \%$ over $2 \mathrm{~min}$. This rate was held for 3 min followed by a linear increase to $90 \%$ methanol over 4 min and held for $2 \mathrm{~min}$. Totally it took $12 \mathrm{~min}$. Using this method, HBCDs were separated with retention times of 7.93, 8.66, and $9.20 \mathrm{~min}$ for $\alpha$-, $\beta$-, and $\gamma$-isomers, respectively. The peak of TBBPA also was shown at $5.40 \mathrm{~min}$. Mass spectrometric analysis was performed in the electro-spray negative ionization mode and in Multiple Reaction Monitoring (MRM) mode for quantitative determination. HBCD isomers were analyzed based on $\mathrm{m} / \mathrm{z}$ 604.3 to 80.8 and TBBPA was based on m/z 542.6 to 78.7.

The detailed QA/QC during the analysis of PBDEs and phthalates is provided in the supplementary materials.

\subsection{Data Analysis}

For statistical analysis, the mean value was obtained by the application of recommended environmental exposure point concentrations ver2.2 (ALCOA Inc.), which was a simple statistical tool using a personal computer. This representative value was called 'EPC (exposure point concentration)' and was calculated by distinction of the distribution characteristics. Results were considered statistically significant, if the p-value was less than 0.05 .

\section{Results and Discussion}

\subsection{Levels of BFRs and Phthalates in House Dust}

The concentration ranges of phthalate esters in all dust samples were summarized in Table 2. Mean concentrations of phthalate esters $\left(1,825 \mu \mathrm{g} \mathrm{g}^{-1}\right)$ were significantly higher than that of BFRs (PBDE: 1,332 $\mathrm{ng} \mathrm{g}^{-1}$, HBCDs: $459 \mathrm{ng} \mathrm{g}^{-1}$, and TBBPA: $213 \mathrm{ng}$ $\mathrm{g}^{-1}$, respectively). This result indicates that phthalates have been

Table 2. Concentrations of PBDEs and Phthalates in the House Dust Samples

\begin{tabular}{|c|c|c|c|c|c|}
\hline Site & Compound & Phthalates $\left(\mu \mathrm{g} \mathrm{g}^{-1}\right)^{1)}$ & PBDEs (ng $\left.g^{-1}\right)^{2)}$ & HBCDs (ng $\left.g^{-1}\right)^{3)}$ & TBBPA (ng $\left.g^{-1}\right)$ \\
\hline house & Min & 175 & 396 & $<\mathrm{LOD}^{4)}$ & $<$ LOD \\
\hline \multirow[t]{3}{*}{$(\mathrm{n}=42)$} & Max & 4,491 & 3,346 & 3,132 & 2,092 \\
\hline & Mean & 1,825 & 1,332 & 459 & 213 \\
\hline & median & 1,550 & 1,257 & 278 & 69 \\
\hline
\end{tabular}

1) esters: DMP, DEP, DIBP, DBP, DMEP, DMPP, DMPP, DEEP, DAP, DHP, BBP, DBEP, DCHP, DEHP, DNOP, DNP (total 15 compounds)

2) congeners: BDE-1, BDE-7, BDE-28, BDE-47, BDE-100, BDE-99, BDE-153, BDE-183, BDE-203, BDE-207, BDE-208, BDE-206, BDE-209 (total 13 compounds)

3) isomers: $\alpha$-HBCD, $\beta$-HBCD, $\gamma$-HBCD

4) below LODs (limit of detection) 
widely used in building materials and electronic equipment, compared to BFRs. Among the BFRS, PBDE concentrations were 3-6 times higher than HBCDs and TBBPA concentrations ( $p$ $<0.05)$. This result might be due to that HBCDs and TBBPA have been used as alternatives to PBDEs only recently compared to PBDEs. Thus, PBDEs levels were still higher than HBCD and TBBPA, indicating that PBDEs have been accumulated to dust since they were used vastly until banned [21].

\section{2. $\Sigma$ PBDE levels in House Dust}

The concentration of each PBDE in the house dust presents in Table 3. The median concentration of $\sum$ PBDEs in the house dust was 1,257 $\mathrm{ng} \mathrm{g}^{-1}$ (ranged 396-3,346 $\mathrm{ng} \mathrm{g}^{-1}$ ). Most PBDE congeners were detected at a high frequency (frequency of 70-100\%), except BDE-28 (23\% frequency) (Table 3). Among PBDE congeners, BDE-206, -208, and -209 were detected in all dust samples (100\%). BDE-47, -99, and -207 were detected with 97\% frequency. BDE-7 (79\%), BDE-28 (23\%), BDE-100 (85\%), and BDE-203 (56\%) were detected at a lower frequency. In contrast, BDE-1, BDE-153, and BDE-183 were not detected in house dust samples. This was consistent with those observed in house dust samples collected in other Korean city [17, 22].

The median concentration of BDE-209 in house dust was highest at $315 \mathrm{ng} \mathrm{g}^{-1}$ (contribution of 25\%). Similar to our result, Lee et al. [22] showed that the predominant congener of PBDEs observed in house dust samples was BDE-209, accounting for $83 \pm 12 \%$ of $\Sigma$ PBDEs. Other Korean study [23] reported that the three congeners of BDE-206, 207, and 209 in all dust samples were detected, and in particular, BDE-209 was found as a dominant congener most of them. In addition, Kim [23] and La Guardia et al. [24] found the relatively high proportions of deca- and nona-BDEs in the profile congeners of the technical mixture products of deca-BDE, such as Saytex 102E or Bromkal 82-0DE. Thus, this result might be due to the intensive use and no regulation of deca-BDE product in Korea [25].

Unlike previous Korean studies [17, 22, 23], BDE-47 (a median
$=304 \mathrm{ng} \mathrm{g}^{-1}$ ) was the secondarily abundant congener, accounting for $24 \%$ of $\Sigma$ PBDEs (Table 3). According to Kim [23] and La Guardia et al. [24], tri- to hexa-BDEs (particularly, BDE-47, 99, and 100) are dominant congeners in penta-BDE product such as DE-71 or Bromkal 70-5DE. From our study, penta-BDE product, containing lighter congeners as the dominant ingredient, might have been used consistently in relative proportion with deca-BDE product in Korea, or breakdown from the heavier congeners to lighter ones in house dust.

As shown in Table 4, the levels of BFRs in our study were compared with those reported in other countries. Although the levels of BFRs in this study are significantly higher than that reported a median concentration of $227 \mathrm{ng} \mathrm{g}^{-1}$ (35-576 $\mathrm{ng} \mathrm{g}^{-1}$ ) in Korean other study [23], the levels of $\Sigma$ PBDE concentration (median; $1,257 \mathrm{ng} \mathrm{g}^{-1}\left(396-3,346 \mathrm{ng} \mathrm{g}^{-1}\right)$ in this study was lower than that in the United States $\left(4,200 \mathrm{ng} \mathrm{g}^{-1}\right)$ and U.K. (8,500 ng g $\left.{ }^{-1}\right)$. DIBP concentration in this study was comparable to that reported from the China and Australia (ranging from 571 to $1,876 \mathrm{ng} \mathrm{g}^{-1}$ ).

\subsection{HBCD and TBBPA Levels in House Dust}

As the alternatives to PBDEs, the median concentrations of HBCDs and TBBPA in house dust were $278 \mathrm{ng} \mathrm{g}^{-1}$ ( $<$ LOD-3,132 $\mathrm{ng} \mathrm{g}^{-1}$ ) and $69 \mathrm{ng} \mathrm{g}^{-1}\left(<\mathrm{LOD}-2,092 \mathrm{ng} \mathrm{g}^{-1}\right.$ ), respectively (Table 5). As shown in Table 5, the $\Sigma$ HBCD concentrations of home dust in the U.K. $\left(2,401\right.$ and $\left.730 \mathrm{ng} \mathrm{g}^{-1}\right)$, Canada (640 ng g $\left.{ }^{-1}\right)$, and the United States (390 $\mathrm{ng} \mathrm{g}^{-1}$ ) showed relatively higher concentrations compared to our results. On the other hand, the studies conducted in New Zealand and Japan reported levels similar with our result $[35,36]$. The lower concentrations of $\Sigma$ HBCD in home dust in Korea could be because Koreans generally do not use carpet in their homes. One previous study reported that carpet probably was one source of HBCD in home dust [39].

As shown in Table 5, the median TBBPA levels in house dust from the United States (200 $\mathrm{ng} \mathrm{g}^{-1}$; ranged 22-2,000 $\mathrm{ng} \mathrm{g}^{-1}$ ) [27], Japan (505 ng g ${ }^{-1}$; ranged 490-520 ng g-1) [37], and the U.K. (87 $\mathrm{ng} \mathrm{g}^{-1}$; ranged < LOD-382 $\mathrm{ng} \mathrm{g}^{-1}$ ) [5] showed relatively

Table 3. Summary of Concentrations of PBDE Congeners in the House Dust Samples

\begin{tabular}{|c|c|c|c|c|c|c|}
\hline Compound $^{1)}$ & $\operatorname{Mean}^{2)}\left(\mathrm{ng} \mathrm{g}^{-1}\right)$ & Median (ng g ${ }^{-1}$ ) & Range (ng $\mathrm{g}^{-1}$ ) & s.d. $\left(n g g^{-1}\right)$ & Proportion $^{3)}$ (\%) & Frequency (\%) \\
\hline BDE-7 & 91 & 87 & $<$ LOD-229 & 69 & 7 & 79 \\
\hline BDE-28 & 11 & $<\mathrm{LOD}$ & $<$ LOD-70 & 21 & - & 23 \\
\hline BDE-47 & 285 & 304 & $<$ LOD-585 & 147 & 24 & 97 \\
\hline BDE-99 & 162 & 76 & $<$ LOD-1,701 & 324 & 6 & 97 \\
\hline BDE-100 & 60 & 45 & $<$ LOD-454 & 75 & 4 & 85 \\
\hline BDE-203 & 37 & 46 & $<$ LOD-122 & 36 & 4 & 56 \\
\hline BDE-206 & 84 & 77 & $33-166$ & 30 & 6 & 100 \\
\hline BDE-207 & 75 & 68 & $40-165$ & 33 & 5 & 97 \\
\hline BDE-208 & 82 & 78 & $36-144$ & 28 & 6 & 100 \\
\hline BDE-209 & 444 & 315 & $61-1,652$ & 321 & 25 & 100 \\
\hline ¿PBDEs & 1,332 & 1,257 & $396-3,346$ & 585 & - & - \\
\hline
\end{tabular}

1) BDE-1, BDE-153, BDE-183 were detected as below LOD

2) Application of recommended environmental exposure point concentrations ver2.2 (ALCOA Inc.)

3) Proportion data was based on the median value 
Table 4. Comparisons of the Concentration of $\sum$ PBDEs with Other Related Studies

\begin{tabular}{|c|c|c|c|c|}
\hline & Country & Median (ng g ${ }^{-1}$ ) & Range (ng g ${ }^{-1}$ ) & Reference \\
\hline \multirow[t]{11}{*}{ House dust } & South Korea $(\mathrm{n}=42)$ & 1,257 & $396-3,346$ & This study \\
\hline & South Korea $(\mathrm{n}=4)$ & 227 & $35-576$ & Kim [23] \\
\hline & United States $(\mathrm{n}=10)$ & 4,200 & $520-29,000$ & Sjödin et al. [26] \\
\hline & United States $(\mathrm{n}=20)$ & 13,723 & $3,020-192,100$ & Allen et al. [6] \\
\hline & United States $(\mathrm{n}=16)$ & 3,931 & $534-85,550$ & Dodson et al. [27] \\
\hline & United Kingdom $(\mathrm{n}=30)$ & 8,500 & $12-220,000$ & Stuart et al. [28] \\
\hline & Australia (n = 10) & 1,200 & $500-13,000$ & Sjödin et al. [29] \\
\hline & Australia (n = 30) & 571 & $61-82,400$ & Stasinska et al. [29] \\
\hline & Germany (n = 10) & 74 & $17-550$ & Sjödin et al. [26] \\
\hline & China $(\mathrm{n}=76)$ & 1,876 & $186-9,654$ & Huang et al. [30] \\
\hline & China $(\mathrm{n}=44)$ & 721 & $132-3,887$ & Yu et al. [31] \\
\hline \multirow[t]{2}{*}{ Sources } & TV dust & 72,134 & & Huang et al. [30] \\
\hline & Computer dust & 6,272 & & Huang et al. [30] \\
\hline
\end{tabular}

Table 5. Comparisons of HBCDs and TBBPA as the Median Values with Other Related Studies

\begin{tabular}{|c|c|c|c|c|c|}
\hline$n g g^{-1}$ & $\alpha$-HBCD & $\beta-H B C D$ & $\gamma$-HBCD & $\sum$ HBCDs & TBBPA \\
\hline This study $(\mathrm{n}=42)$ & $\begin{array}{c}144 \\
(<\text { LOD-1,752) }\end{array}$ & $\begin{array}{c}12 \\
(<\text { LOD-322) }\end{array}$ & $\begin{array}{c}60 \\
(<\text { LOD-2,897) }\end{array}$ & $\begin{array}{c}278 \\
(<\text { LOD-3,132) }\end{array}$ & $\begin{array}{c}69 \\
(<\text { LOD-2,092) }\end{array}$ \\
\hline $\begin{array}{l}\text { Korea }(\mathrm{n}=46) \\
\text { (Barghi et al. [32]) }\end{array}$ & $\begin{array}{c}43 \\
(10-1,327)\end{array}$ & $\begin{array}{c}6 \\
(1-217)\end{array}$ & $\begin{array}{c}46 \\
(\mathrm{ND}-1,101)\end{array}$ & $\begin{array}{c}106 \\
(19-2,645)\end{array}$ & $\begin{array}{c}79 \\
(14-1,212)\end{array}$ \\
\hline $\begin{array}{l}\text { U.K. }(\mathrm{n}=42) \\
\text { (Abdallah and Harrad [33]) }\end{array}$ & $\begin{array}{c}876 \\
(112-40,653)\end{array}$ & $\begin{array}{c}300 \\
(25-25,513)\end{array}$ & $\begin{array}{c}886 \\
(80-74,607)\end{array}$ & $\begin{array}{c}2,401 \\
(228-140,774)\end{array}$ & - \\
\hline $\begin{array}{l}\text { U.K }(\mathrm{n}=31) \\
\text { (Abdallah et al. [34]) }\end{array}$ & $\begin{array}{c}170 \\
(22-66,000)\end{array}$ & $\begin{array}{c}66 \\
(9-7,800)\end{array}$ & $\begin{array}{c}440 \\
(70-37,000)\end{array}$ & $\begin{array}{c}730 \\
(140-110,000)\end{array}$ & \\
\hline $\begin{array}{l}\text { Canada }(\mathrm{n}=8) \\
\text { (Abdallah et al. [34]) }\end{array}$ & $\begin{array}{c}300 \\
(25-670)\end{array}$ & $\begin{array}{c}72 \\
(6-130)\end{array}$ & $\begin{array}{c}230 \\
(34-470)\end{array}$ & $\begin{array}{c}640 \\
(64-1,300)\end{array}$ & - \\
\hline $\begin{array}{l}\text { U.S. }(\mathrm{n}=42) \\
\text { (Abdallah and Harrad [33]) }\end{array}$ & $\begin{array}{c}80 \\
(17-1,800)\end{array}$ & $\begin{array}{c}28 \\
(6-300)\end{array}$ & $\begin{array}{c}300 \\
(79-2,000)\end{array}$ & $\begin{array}{c}390 \\
(110-4,000)\end{array}$ & - \\
\hline $\begin{array}{l}\text { New Zealand }(\mathrm{n}=50) \\
\text { (Ali et al. [35]) }\end{array}$ & $\begin{array}{c}99 \\
(3-1,790)\end{array}$ & $\begin{array}{c}12 \\
(3-270)\end{array}$ & $\begin{array}{c}96 \\
(8-3,020)\end{array}$ & $\begin{array}{c}190 \\
(20-4,100)\end{array}$ & - \\
\hline $\begin{array}{l}\text { Japan }(\mathrm{n}=33) \\
\text { (Tue et al. [36]) }\end{array}$ & $\begin{array}{c}48 \\
(3-340)\end{array}$ & $\begin{array}{c}4.7 \\
(1-34)\end{array}$ & $\begin{array}{c}8 \\
(2-110)\end{array}$ & $\begin{array}{c}120 \\
(5-400)\end{array}$ & - \\
\hline $\begin{array}{l}\text { Belgium }(\mathrm{n}=18) \\
\text { (Geens et al. [8]) }\end{array}$ & - & - & - & - & $\begin{array}{c}10 \\
(1-1,480)\end{array}$ \\
\hline $\begin{array}{l}\text { U.K. }(\mathrm{n}=35) \\
\text { (Abdallah et al. [5]) }\end{array}$ & - & - & - & - & $\begin{array}{c}87 \\
(<\text { LOD-382) }\end{array}$ \\
\hline $\begin{array}{l}\text { U.K. }(\mathrm{n}=35) \\
\text { (Geens et al. [8]) }\end{array}$ & - & - & - & - & $\begin{array}{c}60 \\
(190-340)\end{array}$ \\
\hline $\begin{array}{l}\text { U.S. }(n=16) \\
\text { (Dodson et al. [27]) }\end{array}$ & - & - & - & - & $\begin{array}{c}200 \\
(22-2,000)\end{array}$ \\
\hline $\begin{array}{l}\text { Japan }(\mathrm{n}=2) \\
\text { (Takigami et al. [37]) }\end{array}$ & - & - & - & - & $\begin{array}{c}505 \\
(490-520)\end{array}$ \\
\hline $\begin{array}{l}\text { Korea }(\mathrm{n}=16) \\
\text { (Wang et al. [38]) }\end{array}$ & - & - & - & - & $\begin{array}{c}84 \\
(43-370)\end{array}$ \\
\hline
\end{tabular}

higher concentrations compared to our study. However, the median TBBPA levels in house dust from Belgium $\left(10 \mathrm{ng} \mathrm{g}^{-1}\right)$ and the U.K. (60 $\left.\mathrm{ng} \mathrm{g}^{-1}\right)$ showed relatively lower concentrations compared to our study (Table 5). Recently, Barghi et al. [32] reported the concentrations of TBBPA in indoor dust samples from indoor environments in Korea. The highest TBBPA median concen- tration was found in offices (463.81 $\mathrm{ng} \mathrm{g}^{-1}$ ), followed by schools $\left(204.16 \mathrm{ng} \mathrm{g}^{-1}\right)>$ Kindergartens $\left(185.03 \mathrm{ng} \mathrm{g}^{-1}\right) \geq$ public indoor environments (183.39 $\mathrm{ng} \mathrm{g}^{-1}$ ) > cars (81.37 $\mathrm{ng} \mathrm{g}^{-1}$ ) > homes (78.87 $\mathrm{ng} \mathrm{g}^{-1}$ ).

The levels of HBCDs and TBBPA in the U.K., the United States, and Canada are generally higher than the levels measured 
in this study. This might be because these substances began to be used earlier in these countries as alternatives to PBDEs.

Interestingly, $\alpha$ - and $\gamma$-HBCDs were generally detected at higher levels than $\beta$-HBCD at each site (Table 5). In particular, $\alpha$-HBCD levels were consistently higher than that of $\gamma$-HBCD and $\beta$-HBCD. Especially, $\beta$-HBCD was barely detected ( $\alpha$-: $52 \%, \gamma-: 24 \%$, and $\beta-: 4 \%)$. Barghi et al. [32] reported that the isomeric distribution of HBCD showed a higher contribution of $\alpha$-HBCD compared to $\beta$ - and $\gamma$-HBCD in the collected indoor dust samples except the office samples from Korea. Similar patterns $(\alpha->\gamma->\beta$-HBCD) were found in house dust samples from Canada $(\alpha-: 47 \%, \gamma-$ : $37 \%$, and $\beta-: 16 \%$ ) [34] and Japan ( $\alpha-: 79 \%, \gamma-: 13 \%$, and $\beta-$ : 7\%) [36]. However, Abdallah et al. [5] reported that $\gamma$-HBCD was present at the highest concentration, followed by $\alpha$-HBCD and $\beta$-HBCD in the U.K. ( $\gamma$-: 60\%, $\alpha-: 23 \%$, and $\beta-: 9 \%)$ and the U.S. $(\gamma-: 77 \%, \alpha-: 21 \%$, and $\beta-: 7 \%)$.

\subsection{Phthalates in House Dust}

The median concentration of total phthalates in house dusts in this study was $1,550 \mu \mathrm{g} \mathrm{g}^{-1}\left(175-4,491 \mu \mathrm{g} \mathrm{g}^{-1}\right)$ (Table 6). Among the phthalates, DEHP was highly dominant (median 1,488 $\mu \mathrm{g} \mathrm{g}^{-1}$ ), detected at the levels ranging from 114 to $4,321 \mu \mathrm{g} \mathrm{g}^{-1}$ with $100 \%$ frequency, then followed by DBP (median $18.3 \mu \mathrm{g} \mathrm{g}^{-1}$ ), BBP (median $12.8 \mu \mathrm{g} \mathrm{g}^{-1}$ ), and DIBP (median $2.9 \mu \mathrm{g} \mathrm{g}^{-1}$ ), respectively. DBP, BBP, and DIBP were also detected in the majority of house dust samples. The trend that DEHP was detected at the highest levels, followed by DBP and BBP in dust samples was similar with other studies. Li et al. [18] also reported that DEHP, DBP, and DIBP were the dominant phthalates in dormitory dust. In contrast, DIBP, DNOP, and DHP were detected less frequently. The other phthalates were detected as below LOD.

The concentrations of phthalate esters reported in this study were generally higher than in the levels reported from Europe and the United States, and similar with those measured in Asia (Table 7). The median range for phthalates reported was $500-1,000 \mu \mathrm{g} \mathrm{g}^{-1}$ in Germany, 412-662 $\mu \mathrm{g} \mathrm{g}^{-1}$ in the U.S., 869 $\mu \mathrm{g} \mathrm{g}^{-1}$ in Denmark, and $1,100 \mu \mathrm{g} \mathrm{g}^{-1}$ in Sweden, respectively. On the other hand, higher median values of phthalates were

Table 6. Concentrations $\left(\mathrm{\mu g} \mathrm{g}^{-1}\right)$ of Phthalate Esters in the House Settled Dust

\begin{tabular}{lcclc}
\hline \multicolumn{1}{c}{$\mathbf{g ~ g}^{-\mathbf{1}}$} & Mean $^{\mathbf{1}}$ & Median & Range & Frequency (\%) \\
\hline DIBP & 4.9 & 2.9 & $<$ LOD-21.1 & 81 \\
DBP & 34.6 & 18.3 & $<$ LOD-190.7 & 98 \\
DAP & 0.4 & $<$ LOD & $<$ LOD-4.5 & 17 \\
DHP & 0.1 & $<$ LOD & $<$ LOD-1.1 & 14 \\
BBP & 52.1 & 12.8 & $<$ LOD-444.4 & 74 \\
DEHP & 1,762 & 1,488 & $114-4,321$ & 100 \\
DNOP & 6.2 & 3.9 & $<$ LOD-15.4 & 69 \\
LPhthalate & 1,825 & 1,550 & $175-4,491$ & \\
\hline
\end{tabular}

1) Application of recommended environmental exposure point concentrations ver2.2 (ALCOA Inc.)

2) DMP, DEP, DMEP, DMPP, DEEP, DBEP, DCHP and DNP were detected as below LOD

Table 7. Comparisons of the Concentrations of $\sum$ Phthalate Esters in the House Dusts with Other Studies

\begin{tabular}{|c|c|c|c|c|c|}
\hline Median $\left(\mu \mathrm{g} \mathrm{g}^{-1}\right)$ & $\sum$ Phthalates & DEHP & DBP & BBP & Reference \\
\hline South Korea $(\mathrm{n}=42)$ & 1,550 & 1,488 & 18 & 13 & This study \\
\hline Germany $(\mathrm{n}=29)$ & 1,049 & 970 & 51 & 28 & Butte et al. [40] \\
\hline Germany $(\mathrm{n}=30)$ & 780 & 703 & 47 & 30 & Fromme et al. [9] \\
\hline Germany $(\mathrm{n}=65)$ & 769 & 600 & 47 & 19 & Kersten and Reich [41] \\
\hline Germany $(\mathrm{n}=272)$ & 564 & 450 & 87 & 24 & Pöhner et al. [42] \\
\hline USA $(\mathrm{n}=278)$ & 662 & 480 & 29 & 13 & Nagorka et al. [43] \\
\hline USA $(\mathrm{n}=120)$ & 412 & 340 & 20 & 45 & Rudel et al. [44] \\
\hline Denmark $(n=30)$ & 869 & 604 & 87 & 15 & Langer et al. [45] \\
\hline Sweden $(n=346)$ & 1,100 & 770 & 150 & 135 & Bornehag et al. [19] \\
\hline China $(\mathrm{n}=23)$ & 1,272 & 1,190 & 77 & 5 & Ait Bamai et al. [46] \\
\hline Japan $(\mathrm{n}=128)$ & 1,126 & 1,107 & 17 & 2 & Ait Bamai et al. [46] \\
\hline Kuwait $(\mathrm{n}=21)$ & 2,400 & 2,256 & 45 & 8.6 & Gevao et al. [47] \\
\hline \multicolumn{6}{|l|}{ (Sources) $^{1)}$} \\
\hline PVC linoleum $(n=8)$ & 8,183 & 7,834 & 9 & 271 & This study \\
\hline Deposition adhesive $(\mathrm{n}=2)$ & 22 & 22 & nd & nd & This study \\
\hline PVC adhesive $(\mathrm{n}=2)$ & 2,656 & 3 & 2,653 & nd & This study \\
\hline
\end{tabular}

1) Source concentrations are shown as geometric mean values 
di-BDE

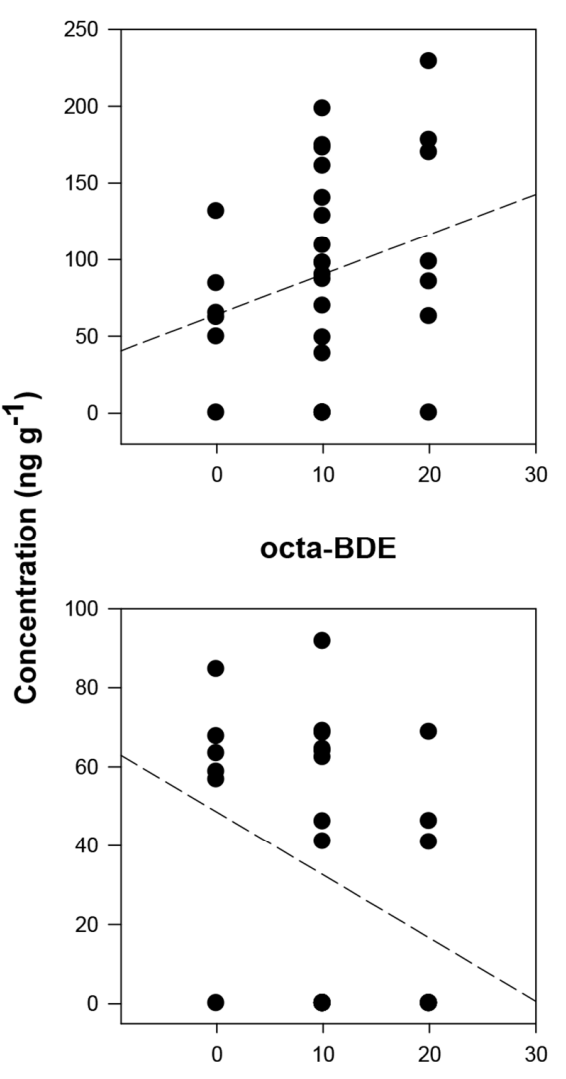

tetra-BDE
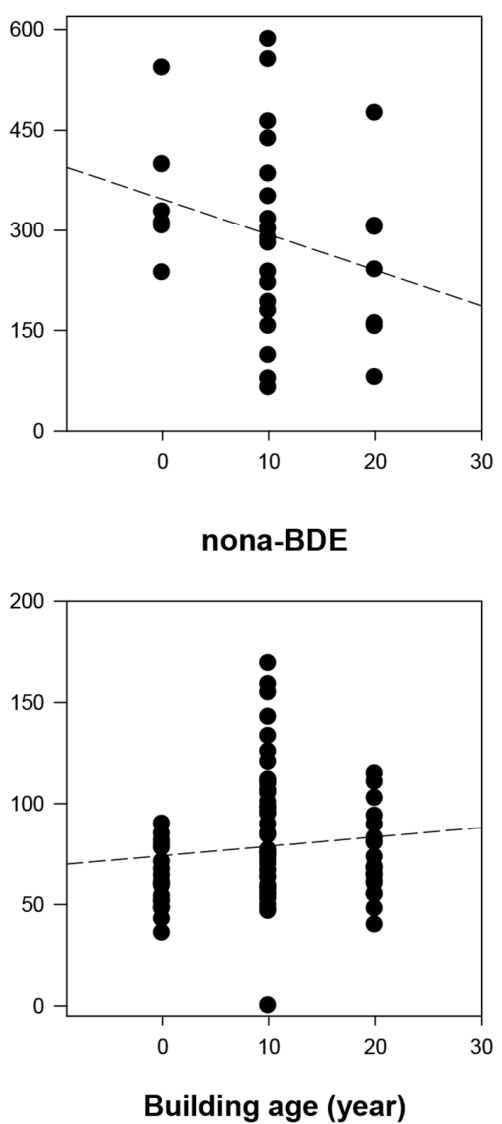

penta-BDE
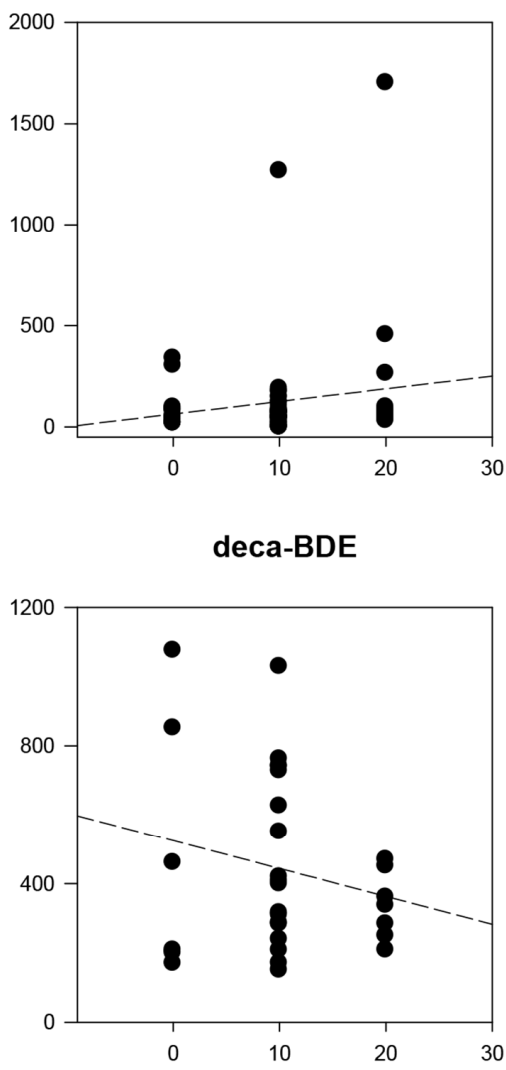

Fig. 1. The relationship between some BFRs concentrations and house age (di-BDE = BDE-7; tetra-BDE $=\mathrm{BDE}-47$; penta-BDE $=\mathrm{BDE}-99+$ BDE-100; octa-BDE = BDE-203; nona-BDE = BDE-206 + BDE-207 + BDE-208; deca-BDE $=$ BDE-209).

observed in Asia $\left(1,550 \mu \mathrm{g} \mathrm{g}^{-1}\right.$ in this study, $1,126 \mu \mathrm{g} \mathrm{g}^{-1}$ in Japan, 1,272 $\mu \mathrm{g} \mathrm{g}^{-1}$ in China, and 2,400 $\mu \mathrm{g} \mathrm{g}^{-1}$ in Kuwait). The higher the levels of phthalates in Korean houses than other countries can be explained by the fact that PVC linoleums, including synthetic PVC adhesives, are more extensively used in the floors in Korean houses. In fact, we measured the phthalates levels in PVC linoleum ( $n=8)$ and PVC adhesive $(n=2)$ used in the sampled houses. The mean concentration of total phthalates in PVC linoleum was $8,183 \mu \mathrm{g} \mathrm{g}^{-1}$, mostly DEHP $(7,834$ $\left.\mu \mathrm{g} \mathrm{g}^{-1}\right)$, and in PVC adhesive, mostly as DBP $\left(2,653 \mu \mathrm{g} \mathrm{g}^{-1}\right)$, indicating that the main source for high concentrations of phthalates are PVC flowing in Korean houses (Table 7).

\subsection{Correlations between the Levels of BFRs and Phthalates with Building Characteristics}

The association analysis between flooring type (PVC or wood) and building age and the concentrations of 13 congeners of PBDEs, HBCDs, and TBBPA was performed. Table S2 presents that the levels of PBDEs, HBCDs and TBBPA showed no association with PVC flooring type, but there was a weak association with building age. Among the PBDE congeners, BDE-47 ( $p=0.062$ ), and BDE-203 ( $p=0.007$ ) were significantly correlated with building age; total HBCDs were also correlated with building age.

As shown in Fig. S2, deca-BDE can be debrominated over time in indoor environment, and the various PBDE congeners can be detected in dust. Hua et al. [48] also observed the reductive debromination of BDE-209 leading to BDE-7 upon solar irradiation. Similar to our result (refer Table 3), Kim [23] reported that the ratio of isomers other than BDE-209 detected in dust was not high, and it could be the result of degradation of environment rather than direct product (penta- or octa-BDE) [23]. Based on these results, although BDE-47 is a dominant congener in penta-BDE product such as DE-71 or Bromkal 70-5DE, BDE-47 might be byproduct of the debromination of BDE-209. Because the concentrations of light congeners (di-BDE to penta-BDE) increased with increasing age of the building and the concentrations of heavy congeners (octa-BDE to deca-BDE) decreased with increasing age of building (Fig. 1)

Next, the association between flooring type and building age, with the concentrations of seven phthalate esters detected was examined. The distribution of surface materials on floors is presented in Table 8. The study cases were PVC-contained linoleums and the wood flooring materials were used as a control. Although 
Table 8. The Associations of the Levels of $\sum$ Phthalate Esters with the Types of Floors in Settled Dust

\begin{tabular}{|c|c|c|c|c|c|c|c|}
\hline \multirow{2}{*}{$\mu \mathrm{g} \mathrm{g}^{-1}$} & \multicolumn{2}{|c|}{ Type of flooring } & \multirow{2}{*}{ p-Value ${ }^{1)}$} & \multicolumn{3}{|c|}{ Construction Age } & \multirow{2}{*}{ p-Value ${ }^{2)}$} \\
\hline & PVC $(n=34)$ & Wood $(n=8)$ & & $<10$ y $(\mathrm{n}=6)$ & $10-20$ y $(n=19)$ & $>20$ y $(n=9)$ & \\
\hline DIBP & $2.9(0.0-21.1)$ & $2.6(0.0-6.6)$ & 0.718 & $4.5(2.6-21.1)$ & $2.4(0.0-16.9)$ & $3.7(0.0-6.1)$ & 0.499 \\
\hline $\mathrm{DBP}$ & $22.9(1.1-190.7)$ & $9.4(0.0-38.1)$ & 0.012 & $13.9(3.3-47.4)$ & $21.9(2.7-190.7)$ & $34.3(1.1-85.0)$ & 0.070 \\
\hline DAP & $0.0(0.0-4.5)$ & $0.0(0.0-2.7)$ & 0.648 & $0.0(0.0-4.5)$ & $0.0(0.0-1.8)$ & $0.0(0.0-3.5)$ & 0.308 \\
\hline $\mathrm{BBP}$ & $12.8(0.0-444.4)$ & $8.6(0.0-47.1)$ & 0.718 & $9.8(0.0-152.5)$ & $8.1(0.0-403.0)$ & $14.1(3.1-444.4)$ & 0.397 \\
\hline DHP & $0.0(0.0-0.8)$ & $0.0(0.0-1.1)$ & 0.498 & $0.0(0.0-0.7)$ & $0.0(0.0-0.7)$ & $0.0(0.0-0.8)$ & 0.565 \\
\hline DEHP & $1,720(415-4,321)$ & $699(114-1,534)$ & 0.001 & $1,179(415-1,602)$ & $1,690(519-4,321)$ & $2,194(1,262-4,279)$ & 0.004 \\
\hline DNOP & $4.5(0.0-15.4)$ & $0.0(0.0-8.4)$ & 0.087 & $3.7(0.0-10.8)$ & $4.9(0.0-15.4)$ & $5.4(0.0-8.6)$ & 0.992 \\
\hline EPhthalate & $1,823(451-4,491)$ & $764(175-1,576)$ & 0.001 & $1,253(451-1,675)$ & $1,784(634-4,491)$ & $2,302(1,295-4,370)$ & 0.004 \\
\hline
\end{tabular}

1) Mann-Whitney U-test regarding differences in phthalate concentration between PVC flooring and wood as flooring material

2) Spearman correlation test of between construction age and phthalate concentration (correlative in case p-value is below 0.01)

a greater number of PVC floors and fewer wood floors were found among the cases, this disparity was due in part to selection bias, and this imbalance did not influence the results of the study. As shown in Table 8, total phthalates were detected at a median concentration of 1,823 $\mathrm{ng} \mathrm{g}^{-1}$ (451-4,491 $\mathrm{ng} \mathrm{g}^{-1}$ ) for PVC flooring, which is considerably higher than the $764 \mathrm{ng} \mathrm{g}^{-1}(175-1,576 \mathrm{ng}$ $\mathrm{g}^{-1}$ ) for wood flooring ( $\left.p=0.001\right)$. The median DEHP and DBP concentrations in dust samples were also significantly higher for PVC flooring compared to wood flooring. In case of DEHP, the median concentration for PVC flooring was $1,720 \mathrm{ng} \mathrm{g}^{-1}$, and that for wood flooring was $699 \mathrm{ng} \mathrm{g}^{-1}$, indicating that PVC flooring was highly associated with a higher DEHP level ( $p=0.001$ ). Regarding DBP, the median concentration in PVC was $22.9 \mathrm{ng}$ $\mathrm{g}^{-1}$, higher than the $9.4 \mathrm{ng} \mathrm{g}^{-1}$ found for wood ( $p=0.012$ ). The correlation between PVC flooring and the phthalate concentrations in dust was higher for DEHP than for BBP. However, in case of other phthalate esters, there were no significant differences between PVC and woods. This result is in agreement with other results. It is reported that PVC flooring is one of major sources of phthalates in indoor dust [49]. In Korea, PVC flooring is common in most residential or commercial buildings [50].

Interestingly, there was a strong correlation between levels of DEHP and total phthalates and older building construction age. The median DEHP levels were 1,179 $\mathrm{ng} \mathrm{g}^{-1}, 1,690 \mathrm{ng} \mathrm{g}^{-1}$, and $2,194 \mathrm{ng} \mathrm{g}^{-1}$ in DEHP ( $\left.p=0.004\right)$ and 1,253 $\mathrm{ng} \mathrm{g}^{-1}, 1,784 \mathrm{ng} \mathrm{g}^{-1}$, and 2,302 $\mathrm{ng} \mathrm{g}^{-1}$ in $\sum$ phthalates $(p=0.004)$ for building construction age less than $10 \mathrm{y}, 10-20 \mathrm{y}$, more than $20 \mathrm{y}$, respectively. This result implies that phthalate levels increase in older houses. Table 7 also presents that DBP showed a partial correlation, and were $13.9 \mathrm{ng} \mathrm{g}^{-1}, 21.9 \mathrm{ng} \mathrm{g}^{-1}$, and $34.3 \mathrm{ng} \mathrm{g}^{-1}(p=0.070)$ as building construction age increases. Similar result was obtained by Bornehag et al. [44]. They found associations between their dust concentrations of DEHP and the amount of VC used as flooring and wall material in the home [51]. Furthermore, high concentrations of DEHP were associated with buildings constructed before 1960 .

\section{Conclusions}

We examined the levels of BFRs and phthalate esters in indoor house dust in Korea. Among PBDE congeners, BDE-209 (deca-BDE) was dominant, followed by BDE-47, BDE-7, and other. We found the ratio of isomers other than BDE-209 detected in dust was not high. In addition, we observed that not only heavy congeners but also light BDE-7 concentrations increased with increasing age of the building. Thus, this might reflect the debromination of BDE-209. The concentrations of $\mathrm{HHBCD}$ and TBBPA were lower than reported in other countries. Among HBCD levels, a-HBCD was present at the highest concentrations, followed by $\gamma$-HBCD and $\beta$-HBCD. The levels of phthalates were higher than those in Europe and the United States. This result is caused by the more frequent use of phthalate sources such as PVC flooring in Korea. Among the phthalates, DEHP was detected at the highest concentrations, followed by DBP and BBP, indicating that DEHP is widely exposed in indoor environment. We also examined the correlation between flooring type (PVC) and building age based on a survey of building characteristics. For PBDE congeners, BDE-47 ( $p=0.062)$ and BDE-203 $(p=0.007)$ were significantly correlated with building age. PVC flooring was highly associated with levels of DEHP ( $p=0.001)$ and BBP ( $p=0.012)$, indicating that PVC flooring is a source of DEHP and BBP, and building construction age was associated with DEHP $(p=0.004)$ and BBP $(p=0.070)$ levels. This result implies that the older buildings can discharge the greater the quantity of phthalate from sources, resulting in higher the exposure to indoor residents.

Our results can increase understanding of the distribution of BFRs and phthalates in indoor dust in houses, and help to provide the basic data for the establishment of guidelines for indoor air quality in Korea.

\section{Supporting Information (Supplementary Materials)}

The results of MDLs for phthalates in dust sample are provided in Table S1. Associations of BFR concentrations of the settled dusts with building characteristics in 42 houses is provide in Table S2. A detailed description of the extraction and analysis procedures of BFRs and phthalates is provided in Fig. S1. The chart of debromination of deca-BDE is provided in Fig. S2. 


\section{Acknowledgments}

This work was supported by the Korea Environment Industry \& Technology Institute (KEITI) through the Technologies for the Water Supply \& Sewerage Policy of Public Technology Program Based Environmental Policy Project funded by Korea Ministry of Environment (MOE) (No. 2016000700005).

\section{References}

1. Sjödin A, Patterson Jr DG, Bergman A. A review on human exposure to brominated flame retardants - Particularly polybrominated diphenyl ethers. Environ. Int. 2003;29:829-839.

2. Choi KI, Lee SH, Osako M. Leaching of brominated flame retardants from TV housing plastics in the presence of dissolved humic matter. Chemosphere 2009;74:460-466.

3. Besis A, Katsoyiannis A, Botsaropoulou E, Samara C. Concentrations of polybrominated diphenyl ethers (PBDEs) in central air-conditioner filter dust and relevance of non-dietary exposure in occupational indoor environments in Greece. Environ. Pollut. 2014;188:64-70.

4. Vonderheide AP, Mueller KE, Meija J, Welsh GL. Polybrominated diphenyl ethers: Causes for concern and knowledge gaps regarding environmental distribution, fate and toxicity. Sci. Total Environ. 2008;400:425-436.

5. Abdallah MAE, Harrad S, Covaci A. Hexabromocyclododecanes and tetrabromobisphenol-A in indoor air and dust in Birmingham, UK: Implications for human exposure. Environ. Sci. Technol. 2008;42:6855-6861.

6. Allen JG, McClean MD, Stapleton HM, Webster TF. Critical factors in assessing exposure to PBDEs via house dust. Environ. Int. 2008;34:1085-1091.

7. Lilienthal H, Verwer CM, van der Ven V, Piersma AH, Vos JG. Exposure to tetrabromobisphenol A (TBBPA) in Wistar rats: Neurobehavioral effects in offspring from a one-generation reproduction study. Toxicology 2008;246:45-54.

8. Geens T, Roosens L, Neels H, Covaci A. Assessment of human exposure to Bisphenol-A, Triclosan and Tetrabromobisphenol-A through indoor dust intake in Belgium. Chemosphere 2009;76:755-760.

9. Fromme H, Lahrz T, Piloty M, Gebhart H, Oddoy A, Ruden $\mathrm{H}$. Occurrence of phthalates and musk fragrances in indoor air and dust from apartments and kindergartens in Berlin. Indoor Air 2004;14:188-195.

10. Jobling S, Reynolds T, White R, Parker MG, Sumpter JP. A variety of environmentally persistent chemicals, including some phthalate plasticizers, are weakly estrogenic. Environ. Health Perspect. 1995;103:582-587.

11. Harris CA, Henttu P, Parker MG, Sumpter JP. The estrogenic activity of phthalate esters in vitro. Environ. Health Perspect. 1997;105:802-811.

12. Hauser R, Calafat A. Phthalates and human health. Oсcup. Environ. Med. 2005;62:806-818.

13. Abb M, Heinrich T, Sorkau E, Lorenz, W. Phthalates in house dust. Environ. Int. 2009;35:965-970.
14. Schecter A, Päpke O, Tung KC, Staskal D, Birnbaum L. Polybrominated diphenyl ethers contamination of United States food. Environ. Sci. Technol. 2004;98:5306-5311.

15. Hazrati S, Harrad S. Causes of variability in concentrations of polychlorinated biphenyls and polybrominated diphenyl ethers in indoor air. Environ. Sci. Technol. 2006;40:7584-7589.

16. Batterman S, Godwin C, Chernyak S, Jia C, Charles S. Brominated flame retardants in offices in Michigan, USA. Environ. Int. 2010;36:548-556.

17. Kim SK, Kim KS, Hong SH. Overview on relative importance of house dust ingestion in human exposure to polybrominated diphenyl ethers (PBDEs): International comparison and Korea as a case. Sci. Total Environ. 2016;571:82-91.

18. Li HL, Song WW, Zhang ZF, et al. Phthalates in dormitory and house dust of northern Chinese cities: Occurrence, human exposure, and risk assessment. Sci. Total Environ. 2016;565:496-502.

19. Bornehag CG, Sundell J, Weschler CJ, et al. The association between asthma and allergic symptoms in children and phthalates in house dust: A nested case-control study. Environ. Health Perspect. 2004;112:1393-1397.

20. Covaci A, Voorspoels S, Ramos L, Neels H, Blust R. Recent developments in the analysis of brominated flame retardants and brominated natural compounds. J. Chromatogr. A. 2007;1153:145-171

21. Law RJ, Allchin CR, de Boer J, et al. Levels and trends of brominated flame retardants in the European environment. Chemosphere 2006;64:187-208.

22. Lee S, Kannan K, Moon HB. Assessment of exposure to polybrominated diphenyl ethers (PBDEs) via seafood consumption and dust ingestion in Korea. Sci. Total Environ. 2013;443:24-30.

23. Kim KK. Contents characteristics of polybrominated diphenyl ethers (PBDEs) in indoor household dust (In Korean). Anal. Sci. Technol. 2013;26:113-119.

24. La Guardia M, Hale RC, Harvey E. Detailed polybrominated diphenyl ether (PBDE) congener composition of the widely used penta-, octa-, and deca-PBDE technical flame-retardant mixtures. Environ. Sci. Technol. 2006;40:6247-6254.

25. Kim SK, Khim JS, Lee KT, et al. Chapter 2. Emission, contamination and exposure, fate and transport, and national management strategy of persistent organic pollutants in South Korea. Dev. Environ. Sci. 2007;7:31-157.

26. Sjödin A, Päpke O, McGahee E, et al. Concentration of polybrominated diphenyl ethers (PBDEs) in household dust from various countries. Chemosphere 2008;73:S131-S136.

27. Dodson RE, Perovich LJ, Covaci A, et al. After the PBDE phase-out: A broad suite of flame retardants in repeat house dust samples from California. Environ. Sci. Technol. 2012;46: 13056-13066.

28. Stuart H, Ibarra C, Abdallah MAE, Boon R, Neels H, Covaci A. Concentrations of brominated flame retardants in dust from United Kingdom cars, homes, and offices: Causes of variability and implications for human exposure. Environ. Int. 2008;34:1170-1175.

29. Stasinska A, Reid A, Hinwood A, et al. Concentrations of polybrominated diphenyl ethers (PBDEs) in residential dust 
samples from Western Australia. Chemosphere 2013;91:187-193.

30. Huang Y, Chen L, Peng X, Xu Z, Ye Z. PBDEs in indoor dust in South-Central China: Characteristics and implications. Chemosphere 2010;78:169-174.

31. Yu YX, Pang YP, Li C, et al. Concentrations and seasonal variations of polybrominated diphenyl ethers (PBDEs) in in-and out-house dust and human daily intake via dust ingestion corrected with bioaccessibility of PBDEs. Environ. Int. 2012;42:124-131.

32. Barghi M, Shin ES, Kim JC, Choi SD, Chang YS. Human exposure to HBCD and TBBPA via indoor dust in Korea: Estimation of external exposure and body burden. Sci. Total Environ. 2017;593-594:779-786.

33. Abdallah MAE, Harrad S. Personal exposure to HBCDs and its degradation products via ingestion of indoor dust. Environ. Int. 2009:35:870-876.

34. Abdallah MAE, Harrad S, Ibarra C, et al. Hexabromocyclododecanes in indoor dust from Canada, the United Kingdom, and the United States. Environ. Sci. Technol. 2008;42:459-464

35. Ali N, Dirtu AC, Eede NVD, et al. Occurrence of alternative flame retardants in indoor dust from New Zealand: Indoor sources and human exposure assessment. Chemosphere 2012;88:1276-1282.

36. Tue NM, Takahashi S, Suzuki G, et al. Contamination of indoor dust and air by polychlorinated biphenyls and brominated flame retardants and relevance of non-dietary exposure in Vietnamese informal e-waste recycling sites. Environ. Int. 2013;51:160-167.

37. Takigami H, Suzuki G, Hirai Y, Sakai S. Brominated flame retardants and other polyhalogenated compounds in indoor air and dust from two houses in Japan. Chemosphere 2009;76:270-277.

38. Wang W, Abualnaja KO, Asimakopoulos AG, et al. A comparative assessment of human exposure to tetrabromobisphenol A and eight bisphenols including Bisphenol A via indoor dust ingestion in twelve countries. Environ. Int. 2015;83:183-191.

39. Carignan CC, Abdallah MA, Wu N, et al. Predictors of tetrabromobisphenol-A (TBBP-A) and hexabromocyclododecanes (HBCD) in milk from Boston mothers. Environ. Sci. Technol. 2012;46:12146-12153.
40. Butte W, Hostrup O, Walker G. Phthalate im Hausstaub und in der Luft: Assoziationen und mögliche Quellen in Wohnräumen. Gefahrstoffe Reinhalt Luft 2008;68:79-81.

41. Kersten W, Reich T. Schwer flüchtige organische Umweltchemikalien in Hamburger Hausstäuben. Gefahrstoffe Reinhalt Luft 2003;63:85-91.

42. Pöhner A, Simrock S, Thumulla J, Weber S, Wirkner T. Hintergrundbelastung des hausstaubes von privathauhalten mit mittel-und schwerfluchtigen organischen schadstoffen. Umwelt Gesundheit 1997;2:e64.

43. Nagorka R, Scheller C, Ullrich D. Weichmacher im Hausstaub. Gefahrstoffe Reinhalt Luft 2005;65:99-105.

44. Rudel RA, Camann DE, Spengler JD, Korn LR, Brody JG. Phthalates, alkylphenols, pesticides, polybrominated diphenyl ethers, and other endocrine-disrupting compounds in indoor air and dust. Environ. Sci. Technol. 2003;37:4543-4553.

45. Langer S, Weschler CJ, Fischer A, Bekö G, Toftum J, Clausen G. Phthalate and PAH concentrations in dust collected from Danish homes and daycare centers. Atmos. Environ. 2010;44: 2294-2301.

46. Ait Bamai Y, Araki A, Kawai T, et al. Associations of phthalate concentrations in floor dust and multi-surface dust with the interior materials in Japanese dwellings. Sci. Total Environ. 2014;468:147-157.

47. Gevao B, Al-Ghadban AN, Bahloul M, Uddin S, Zafar J. Phthalates in indoor dust in Kuwait: Implications for non-dietary human exposure. Indoor Air 2013;23:126-133.

48. Hua I, Kang NG, Jafvert CT, Fabrega-Duque J. Heterogeneous photochemical reactions of decabromodiphenyl ether. Environ. Toxicol. Chem. 2003;22:798-804.

49. Clausen P, Hansen V, Gunnarsen L, Afshari A, Wolkoff P. Emission of di-2-ethylhexyl phthalate from PVC flooring into air and uptake in dust: Emission and sorption experiments in FLEC and CLIMPAQ. Environ. Sci. Technol. 2004;38:2531-2537.

50. Jeon S, Kim KT, Choi K. Migration of DEHP and DINP into dust from PVC flooring products at different surface temperature a school. Sci. Total Environ. 2016;547:441-446.

51. Bornehag CG, Lundgren B, Weschler CJ, Sigsgaard T, Hagerhed-Engman L, Sundell J. Phthalates in indoor dust and their association with building characteristics. Environ. Health Perspect. 2005;113:1399-1404. 